\title{
Commentary: A Star Story of War: NATO's Dangerous Plan for Space Domination
}

\author{
Tamara Lorincz
}

Balsillie School of International Affairs at Wilfrid Laurier University

\begin{abstract}
For the Indigenous peoples of the land that is now Canada, the heavens are where life originated. The Anishinaabeg believe that when humans die, they pass through the spirit world to the stars. At night, they see their ancestors dance across the sky. For the Indigenous people, there is a sacred, spiritual connection between the earth and the star world. In the constellations, the Anishinaabeg see loons, moose, bear, thunderbirds, and turtles. They have their own names for the constellations. The Big Dipper Stars are known as the Fisher Stars. The Pleiades star cluster is known as the Seven Daughters of the Moon and Sun. The light and patterns in the sky guide their hunting and ceremonies. The Indigenous people remind us that there is one sky, but many ways of seeing and understanding it. How do our Western governments and militaries view the sky? What is their star story? Outer space is seen as a new contested area of competition, conflict and power projection.
\end{abstract}

Keywords: star, Indigenous, Anishinaabeg, NATO, UN, space domination, Space Force, National Defense Authorization Act, Conference of Defence Associations Institute

\section{Una historia de guerra estelar: el peligroso plan de la OTAN para dominar el espacio}

\section{RESUMEN}

Para los pueblos indígenas de la tierra que ahora es Canadá, los cielos son el origen de la vida. Los Anishinaabeg creen que cuando los humanos mueren, atraviesan el mundo espiritual hasta las estrellas. Por la noche, ven a sus antepasados bailar por el cielo. Para los indígenas, existe una conexión espiritual sagrada entre la tierra y el mundo de las estrellas. En las constelaciones, los Anishinaabeg ven somormujos, alces, osos, pájaros del trueno y tortugas. Tienen sus propios nombres para las constelaciones. Las Big Dipper Stars 
se conocen como Fisher Stars. El cúmulo de estrellas de las Pléyades se conoce como las Siete Hijas de la Luna y el Sol. La luz y los patrones en el cielo guían su caza y ceremonias. Los indígenas nos recuerdan que hay un cielo, pero muchas formas de verlo y entenderlo. ¿Cómo ven el cielo nuestros gobiernos y militares occidentales? ¿Cuál es su historia estrella? El espacio ultraterrestre se ve como una nueva área en disputa de competencia, conflicto y proyección de poder.

Palabras clave: estrella, OTAN, ONU, dominio espacial, Fuerza Espacial, Ley de Autorización de Defensa Nacional, Instituto de Asociaciones de la Conferencia de Defensa

\section{星空战争故事：北约危险的太空主导计划}

摘要

对居住在如今属于加拿大领土的土著人民而言, 天空是生命 起源的地方。阿尼新纳贝格人 (Anishinaabeg) 相信当人们 去世时, 他们通过精神世界前往星空。在晚上, 他们看见祖 先在星空中跳舞。对土著人民而言, 地球和星空世界之间存 在一个神圣的精神联系。在各星座中, 阿尼新纳贝格人看见 潜鸟、麇鹿、熊、雷鸟和海龟。他们给不同星座赋予自己 创造的名字。北斗七星被他们称作鱼貂星（Fisher Stars）。 昂宿星团被称作月亮和太阳的七个女儿（Seven Daughters of the Moon and Sun）。天空中的光和模式指引他们的狩猎和仪 式。土著人民提醒我们, 虽然仅有一个天空, 但却有多个看 待和解读它的方式。我们的西方政府和军事如何看待天空? 他们的星空故事是什么? 外太空被视为一个关于竞争、冲突 和权力投射的新争夺领域。

关键词：星球, 北约, 联合国, 太空主导, 太空军, 国防授 权法, 国防协会会议研究所

\section{Introduction}

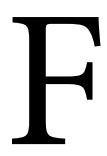

Tor this year's World Space Week, I've been contemplating Indigenous cosmological knowledge and teachings. I live in Waterloo, On- tario on the traditional territory of the Anishinaabeg, Haudenosaunee, and Neutral peoples along the Grand River. With their oral tradition, they have passed on their unique stories of the sky and stars. 
For the Indigenous peoples of the land that is now Canada, the heavens are where life originated. The Anishinaabeg believe that when humans die, they pass through the spirit world to the stars. At night, they see their ancestors dance across the sky. For the Indigenous people, there is a sacred, spiritual connection between the earth and the star world.
In the constellations, the Anishinaabeg see loons, moose, bear, thunderbirds, and turtles. They have their own names for the constellations. The Big Dipper Stars are known as the Fisher Stars. The Pleiades star cluster is known as the Seven Daughters of the Moon and Sun. The light and patterns in the sky guide their hunting and ceremonies.

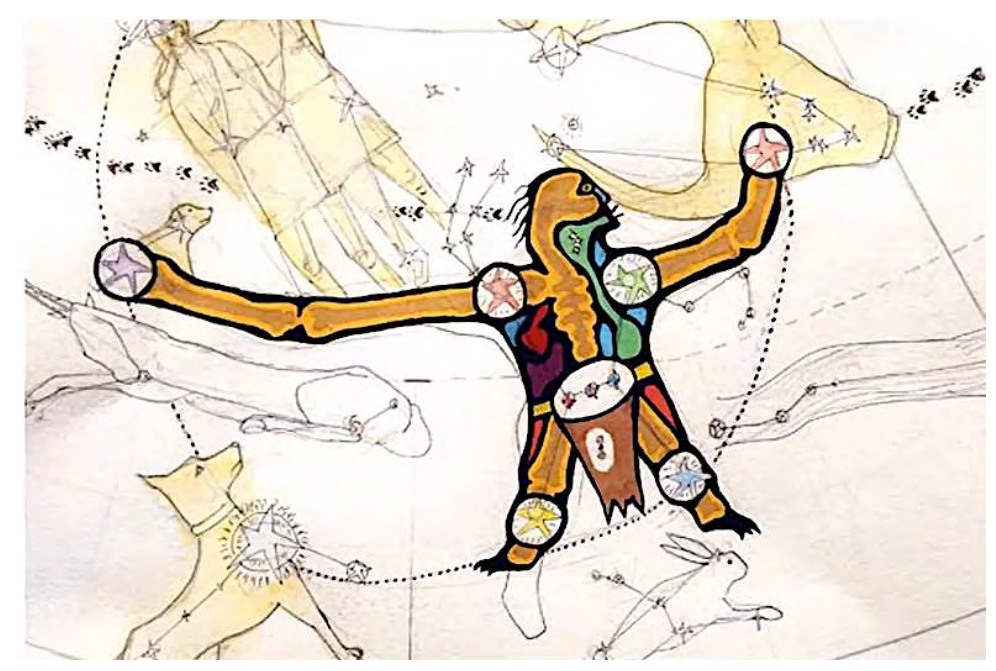

Figure 1. Sky Star Map

The Indigenous people remind us that there is one sky, but many ways of seeing and understanding it. How do our Western governments and militaries view the sky? What is their star story? Outer space is seen as a new contested area of competition, conflict and power projection.

Over the past two years, the United States and its North Atlantic Treaty Organization (NATO) allies have launched a dangerous narrative of space as a place for war. Last August, when President Trump launched the new military service "Space Force," he said space will be the next "war fighting domain." NATO is perpetuating this perilous conceptualization.

\section{North Atlantic Treaty Organization (NATO) and Expanding Militarism}

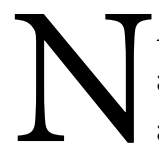
ATO is an aggressive, nuclear-armed Western military alliance that is dominated by the United States. It is comprised of 30 members, including Canada, which was 
one of the twelve founding members in 1949. NATO also has its so-called "partnership for peace" program that includes 40 non-member countries, such as Australia, New Zealand, Japan, South Korea and Afghanistan. With a neocolonial, militarized view of security, the alliance is expanding.

In 2018, Colombia became NATO's first Latin American partner. Yet Colombia is a narco-state ruled by the right-wing government of President Ivan Duque. The Colombian government has connections to drug trafficking and is undermining the 2016 peace deal in the country. Colombia is one of the most militarized and violent countries in South America. According to the non-governmental organization Global Witness, Colombia is a country where journalists are threatened and attacked and where human rights defenders are being killed in the hundreds. Last year, 300 human rights defenders and social movement leaders were murdered. Colombia is one of the closest U.S. allies in the region and has escalated conflict with its neighbour, Venezuela.

Just as we must critically question why Colombia is the first country that NATO has partnered with in Latin America, so too must we raise concerns about the alliance's expansion into space.

\section{NATO and Space for War-Making}

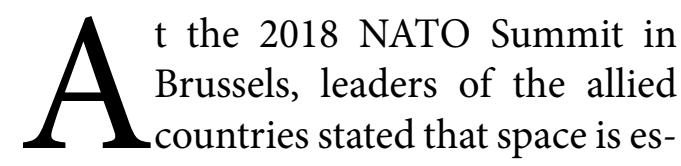

sential for their security, and they agreed to develop a Space Policy. The following year, the NATO Defence Ministers met at the alliance's headquarters and adopted their first Space Policy. Until that point, the transatlantic alliance did not have a space mandate.

In December 2019, at the Leaders' summit in London, NATO members announced space as a fifth domain alongside air, land, sea, and cyberspace. NATO Secretary General Jens Stoltenberg stated, "We have declared space an operational domain recognising its importance in keeping us safe and tackling security challenges, while upholding international law." Although he said NATO has no intention to put weapons in space, there is a lack of transparency about the alliance's plans.

NATO's Space Policy is not publicly available. I contacted NATO Headquarters to ask for a copy, and they replied that it is classified. We can only speculate on what NATO's plans for space are based on its belligerent operations on Earth and its destabilizing expansion in Eastern Europe and Latin America.

Currently, there are more than 2,000 satellites orbiting the Earth, approximately half of which are owned by NATO member countries. The alliance operates its own satellite communications (SATCOM) programme. Though some of those satellites are defunct, they are still orbiting the Earth and carrying the NATO logo. Last year, NATO authorized 1 billion EUR for a new SATCOM service over the next 15 years. 


\section{NATO Is Preparing for War in Space}

The 29 member alliance is poised to declare space a potential war zone.



Figure 2. Popular Mechanics headline "NATO Is Preparing for War in Space" Courtesy Getty Images

\section{NATO October 2020 - Space Week Tweet}

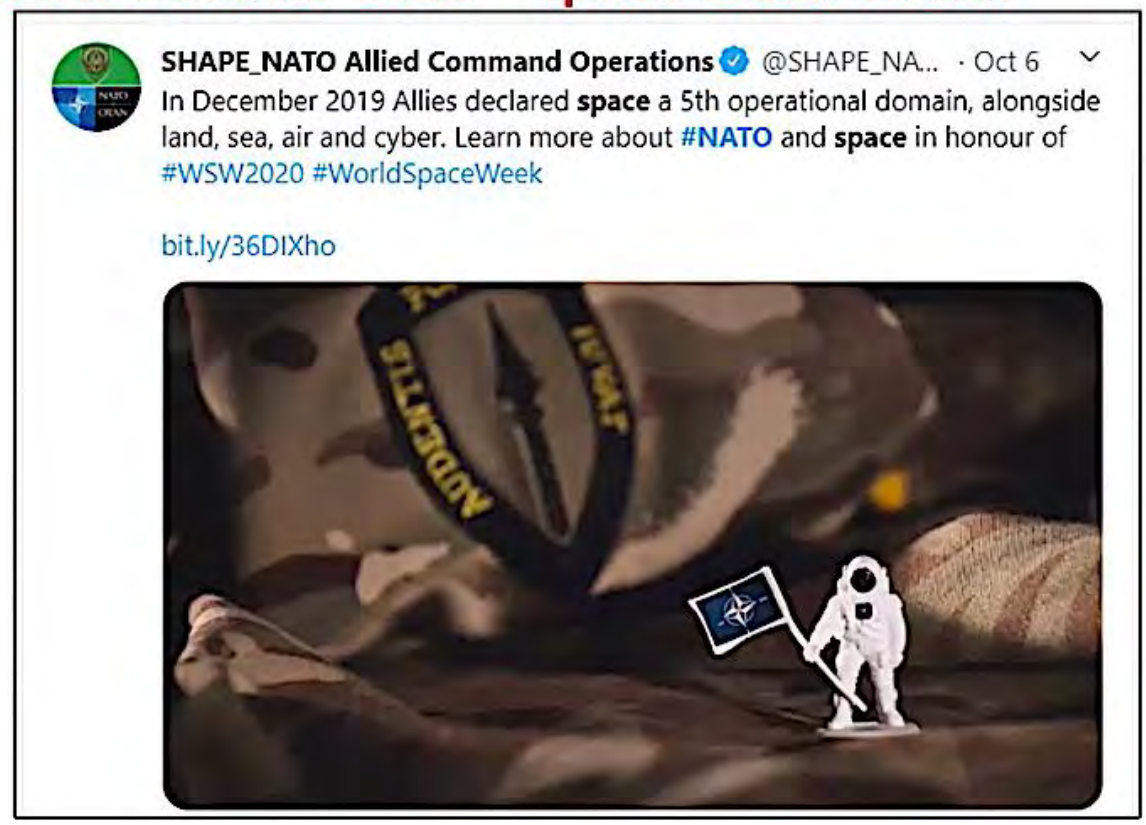

Figure 3. Space Week Tweet by SHAPE NATO Allied Command Operations 
NATO chiefly relies on the national space capabilities from its dominant members, the United States, United Kingdom, and Germany, to provide data and services, such as imagery, navigation, targeting and early warning. These space capabilities enable NATO's war-making.

Last October, NATO announced its new Space Center at its Allied Air Command at Ramstein Air Base in Germany. NATO and the U.S. have used the space capabilities at Ramstein to direct their military operations and drone strikes in Iraq, Syria, Afghanistan, and Pakistan.

Russia and China are the only peer competitors to NATO in space. It is troubling that the transatlantic alliance constantly invokes adversarial Cold War rhetoric against these two countries. On Earth, NATO has also threateningly positioned its soldiers and weapons systems closer to Russia's and China's borders. Conflict in space between NATO and Russia or China could be disastrous and risk an all-out nuclear war.

Yet Russia and China don't want space used as a new battleground. At the United Nations Conference on Disarmament, they have put forward their joint draft treaty on the prevention of an arms race in outer space in 2008, 2014, and 2018. However, primarily because of NATO member countries' reluctance and opposition, this draft treaty to prevent war in space has not moved forward at the UN.

\section{NATO Military Spending and Profiting from Weapons}

$\mathrm{I}$

$\mathrm{n}$ the mid-1990s, American weapons manufacturers pushed for NATO expansion into Eastern Europe. They saw the region as a new subsidized market for their weapons systems. Today, NATO members are required to modernize their militaries and upgrade their capabilities across all domains to stay interoperable with allies.

In 2014, at the Wales Summit, NATO members pledged to increase their defence budgets to $2 \%$ of GDP by 2024 and to spend $20 \%$ of that amount on procurement including space technologies. Over the past five years, military spending by alliance members has increased drastically.

Just as conflict and competition on the Earth is good for profit-making for the weapons manufacturers, so too is it in space. Two years ago, it was reported that the U.S. military was not keen on a new Space Force because many defense officials thought it would be redundant and too costly.

Yet congressmen, backed by defence contractors, pushed for a new space service in the National Defense Authorization Act (NDAA) in 2018. The following year, Mark Esper, the U.S. Secretary of Defense at the time, strongly advocated for Space Force. Esper, though, was the former top lobbyist for Raytheon, a contractor that manufactures space and airborne sensor systems used by the U.S. military.

In Canada, the Conference of Defence Associations Institute (CDAI) 
applauded Trump's announcement of Space Force. The CDAI said "U.S. Space Force was a good idea" and that Canada should have one too. It is not surprising that this Canadian industry group, which is funded by the U.S. weapons manufacturers-Raytheon, Lockheed Martin, and L3 Harris-is supportive of a Canadian space force. Other NATO allies are also establishing new space forces such as the United Kingdom and France.

With well-funded public relations and lobbying, the weapons manufacturers magnify the U.S. military's and NATO's view of space as a warfighting domain to serve their private, profit-making interests. At this time when funding is desperately needed for the global health care crisis, the climate emergency and to achieve the United Nations' Sustainable Development Goals, NATO's pressure on members to spend more on their militaries is grossly irresponsible.

\section{Creating a New Star Story of Cooperation and Peace}

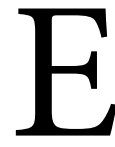
arlier this year, NATO Secretary General Jens Stoltenberg announced a new plan entitled, NATO 2030: United for a New Era. It is an initiative to keep NATO strong militarily and to expand it politically. For outer space, the alliance sees it as essential to its "ability to win on the battlefield." We cannot let NATO weaponize and dictate our star story.



Figure 4. NATO Keep Space for Peace. 
We do not need NATO at all. The the peaceful uses of space. Similar to United Nations comprises all $193 \mathrm{mem}$ - the Anishinaabeg, space should be a site ber countries and has inclusive agen- of shared heritage and humanity. With cies, legal instruments, and diplomatic Indigenous wisdom and international mechanisms that facilitate cooperation solidarity, the story of space as a global and conflict mediation. It is through the common that needs to be protected and UN that countries should establish the preserved for peace is possible. shared norms and state behaviour for

Tamara Lorincz is a PhD candidate at the Balsillie School of International Affairs at Wilfrid Laurier University, and a board director of the Global Network Against Weapons and Nuclear Power in Space. She is also a member of the Canadian Voice of Women for Peace and a fellow with the Canadian Foreign Policy Institute.

\section{References}

Canadian Heritage Information Network, "The Story of the Fisher Constellation," Virtual Museum: http://www.virtualmuseum.ca/edu/ViewLoitDa.do?method= preview\&lang=EN\&id $=14058$

CBC Radio, "We call ourselves the star people': Trace explores Anishinaabe star story through dance," 7 January 2021: https://www.cbc.ca/radio/unreserved/wecome-from-the-stars-indigenous-astronomy-astronauts-and-star-stories1.5861762/we-call-ourselves-the-star-people-trace-explores-anishinaabe-starstory-through-dance-1.5864935

Coles, T.J. “The Space Force Becomes a Weapons System, Arms Companies Profit” Counterpunch, 28 February 2020: https://www.counterpunch.org/2020/02/28/ the-space-force-becomes-a-weapons-system-arms-companies-profit/

Rakobowchuk, P. "Military expert suggests Canada may want to consider its own space force," CBC, 5 January 2019: https://www.cbc.ca/news/politics/ space-force-canada-1.4967295

Global Witness "Enemies of the State: How governments and business silence land and environmental defenders," 2019: https://www.globalwitness.org/en/cam paigns/environmental-activists/enemies-state/

Griffin, O. “Colombia was deadliest country for land rights activists in 2019," Reu- 
ters, 29 July 2020: https://www.reuters.com/article/us-colombia-violence-environ ment-idUSKCN24U16G

Hartung, W. "Pentagon Welfare: The Corporate Campaign for NATO Expansion,” Multinational Monitor, March 1998: https://www.multinationalmonitor.org/mm 1998/031998/hartung.html

Lakhani, N. "More than 300 human rights activists were killed in 2019, report reveals," The Guardian, 14 January 2020: https://www.theguardian.com/law/2020/ jan/14/300-human-rights-activists-killed-2019-report

Lee, A. "Native Skywatchers” https://nativeskywatchers.com/

Mortillaro, N. 'We come from the stars': How Indigenous peoples are taking back astronomy," CBC, 30 March 2019: https://www.cbc.ca/news/technology/indige nous-astronomy-1.5077070

NATO, “London Declaration," 4 December 2019: https://www.nato.int/cps/en/na tohq/official_texts_171584.htm

NATO, "NATO 2030: United for a New Era," 2020: https://www.nato.int/nato_stat ic_fl2014/assets/pdf/2020/12/pdf/201201-Reflection-Group-Final-Report-Uni. pdf

NATO, "NATO Agrees New Space Centre at Allied Air Command," 2020: https:// ac.nato.int/archive/2020/NATO_Space_Centre_at_AIRCOM

Paulauskas, K. “Space: NATO’s latest frontier” NATO, 13 March 2020: https://www. nato.int/docu/review/articles/2020/03/13/space-natos-latest-frontier/index.html

Serbu, J. “House panel votes to split Air Force, create new U.S. Space Corps,” Defense News, Federal News Network, 29 June 2017: https://federalnewsnetwork. com/defense-news/2017/06/house-panel-votes-to-split-air-force-create-new-u-sspace-corps/

Taylor, C. "Relearning the Star Stories of Indigenous Peoples," Science Friday, 6 September 2019: https://www.sciencefriday.com/articles/indigenous-peoples-as tronomy/

United Nations, Office of Disarmament Affairs, Outer Space: https://www.un.org/ disarmament/topics/outerspace/

United States, Department of Defense, National Defense Strategy, 2018: https:// www.defense.gov/Explore/Spotlight/National-Defense-Strategy/ 
Wassegijig Price, M. "INDIGENOUS ASTRONOMY," Blog: https://www.michaelwassegijig.com/star-knowledge.html

Winter, L. "U.S. Space Force: The race to control the space above the sky," Al Jazeera, 29 August 2019: https://www.aljazeera.com/economy/2019/08/29/us-space-forcethe-race-to-control-the-space-above-the-sky/ 